УДК 341.6

\title{
HISTORICAL DEVELOPMENT OF THE CONCEPT OF NON- VIOLATION COMPLAINTS IN INTERNATIONAL ECONOMIC LAW
}

\section{ІСТОРИЧНИЙ РОЗВИТОК КОНЦЕПЦІЇ СКАРГ БЕЗ ПОРУШЕННЯ В МІЖНАРОДНОМУ ЕКОНОМІЧНОМУ ПРАВІ}

\section{ИСТОРИЧЕСКОЕ РАЗВИТИЕ КОНЦЕПЦИИ ЖАЛОБ БЕЗ НАРУШЕНИЯ В МЕЖДУНАРОДНОМ ЭКОНОМИЧЕСКОМ ПРАВЕ}

\section{Skrynka D.V.}

Associate Professor, PhD, Taras Shevchenko National University of Kyiv, Institute of International Relations, International Law Department. dmitryska@gmail.com

\section{Скринька Д. В.}

кандидат юридичних наук, доцент, доцент кафедри міжнародного права Інституту міжнародних відносин Київського національного університету імені Тараса Шевченка. Електронна пошта: dmitryska@gmail.com

\section{Скрынька Д. В.}

кандидат юридических наук, доцент, доцент кафедры международного права Института международных отношений Киевского национального университета имени Тараса Шевченко. Электронная почта: dmitryska@gmail.com

Анотація. Стаття містить короткий огляд історичних коренів $i$ прочесу розробки положень про скарги без порушення в різних міжнародних правових угодах, включаючи Генеральну угоду про тарифи й торгівлю та інші угоди СОТ. Вона вказує на зв'язок між поступовим переходом від умовного до безумовного режиму найбільшого сприяння та запровадженням положення про зменшення або зведення до нуля торгових переваг. В статті вказується на той факт, щчо, хоча система правових норм СОТ набагато більш детальна, ніж система правових норм ГАТТ, пункт про скарги без порушення не тільки залишився в первісному тексті ГАТТ, а й був включений в ряд інших угод СОT.

У статті зазначається, що сама необхідність включення положень про скарги без порушення до міжнародних торговельних угод пов'язана з глобальним прочесом поступового запровадження положень про безумовне надання режиму найбільшого сприяння (на відміну від більш ранньої договірної практики, коли режим найбільшого сприяння надавався на умовній основі).

Стаття вказує на те, що одну з перших спроб встановити принцип безумовного режиму найбільшого сприяння як глобальний єдиний підхід було зроблено на Лондонській Всесвітній економічній конференщії, найбільш амбітній глобальній спробі зробити це до успішного укладення Генеральної угоди про тарифи і торгівлю 1947 року.

Незважаючи на те, що первісною причиною для використання клаузули про скарги без порушення є відносно обмежена сфера застосування Генеральної угоди про тарифи та торгівлю, значне розширення сфери застосування иієї багатосторонньої торговельної системи в результаті Уругвайського раунду багатосторонніх торговельних переговорів не призвело до усунення первісного положення про скарги без порушення з тексту ГАТТ. Більше того, положення про скарги без порушення були включені до ряду інших угод СОТ. Це, у свою чергу, підводить до питання, чи дійсно можна було б в майбутньому укласти міжнародну торговельну угоду, яка б 
охоплювала кожний захід, що впливає на міжнародну торгівлю, доступний для національних урядів.

Ключові слова. СОТ, ГАТТ, торговельні угоди, зведення нанівещь торговельних переваг, зменшення торговельних переваг, взаємність, клаузула про скарги без порушення, клаузула про режим найбільшого сприяння.

Abstract. The article contains a brief review of historical roots and process of development of the non-violation clauses in various international legal agreements, including the General Agreement on Tariffs and Trade and other WTO agreements. It points out the connection between the gradual transition from conditional to unconditional most-favorednation treatment and the introduction of the clause about nullification or impairment of benefits. Finally, the article points out the fact that even though the WTO system of legal rules is much more detailed than the GATT system of legal rules, the non-non-violation clause not only remained in the original text of the GATT, but also was included in a number of other WTO agreements.

The article notes that the very need to introduce non-violation clauses in international trade treaties is connected with the global process of gradual introduction of unconditional most favored treatment clauses (in contrast to earlier treaty practice, where most-favorednation treatment was provided on a conditional basis).

The article points out that one of the earliest attempts to establish the principle of unconditional most-favored-nation treatment as a global uniform approach was made at the London World Economic Conference, the most ambitious global attempt to do so before the successful conclusion of the General Agreement on Tariffs and Trade in 1947.

Even though the original cause for non-violation complaints has been a relatively limited scope of the General Agreement on Tariffs and Trade, the significant expansion of the scope of application of this multilateral trade system as a result of the Uruguay Round of multilateral trade negotiations did not result in the removal of the original non-violation clause from the text of the GATT. Moreover, non-violation clauses were included in a number of other WTO agreements. This, in turn, leads to a question, whether indeed it would be possible at any time in the future to conclude an international trade agreement, which would cover each and every measure affecting international trade, available to national governments.

Keywords: WTO, GATT, trade agreements, nullification of benefits, impairment of benefits, reciprocity, non-violation clause, most-favored-nation clause.

Аннотация. Статья содержит краткий обзор исторических корней и прочесса разработки положений о жалобах без нарушения в различных международных правовых соглашениях, включая Генеральное согламение о тарифах и торговле и другие соглашения ВТО. Она указывает на связь между постепенным переходом от условного к безусловному режиму наибольшего благоприятствования и введением положения об уменьшении или сведении к нулю торговых преимуществ. Наконеи, в статье указывается на тот факт, что, хотя система правовых норм ВТО гораздо более детальна, чем система правовых норм ГАТТ, пункт о недопущении нарушений не только остался в первоначальном тексте ГАТТ, но и был включен в ряд других соглашений ВТО.

В статье отмечается, что сама необходимость включения положений о жалобах без нарушения в международные торговые согламения связана с глобальным прочессом постепенного введения положений о безусловном предоставлении режима наибольшего благоприятствования (в отличие от более ранней договорной практики, когда режим наибольшего благоприятствования предоставлялся на условной основе) .

Статья указывает на то, что одной из первых попыток установить принцип безусловного режима наибольшего благоприятствования как глобальный единый 
подход, была Лондонская Всемирная экономическая конференция, наиболее амбиииозная глобальная попытка сделать это до успешного заключения Генерального соглашения о тарифах и торговле 1947 года.

Несмотря на то, что первоначальной причиной для жалоб без нарушения является относительно ограниченная сфера применения Генерального согламения о тарифах и торговле, значительное расширение сферы применения этой многосторонней торговой системы в результате Уругвайского раунда многосторонних торговых переговоров не привело к исключению первоначального положения о жалобах без нарушения из текста ГАТТ. Более того, положения о жалобах без нарушения были включены в ряд других соглашений ВТО. Это, в свою очередь, подводит к вопросу, действительно ли можно было бы в будущем заключить международное торговое согламение, которое охватывало бы каждое мероприятие, влияющее на международную торговлю, доступное для начиональных правительств.

Ключевые слова. ВТО, ГАТТ, торговые соглачения, аннулирование торговых преимуществ, уменьшение торговых преимуществ, взаимность, клаузула о жалобах без нарушения, клаузула о режиме наибольшего благоприятствования.

\section{The text of the article}

\section{The description of the issues}

It is important in the current context of regionalist and globalist tendencies in the regulation of regulatory activities of the states to understand the historical origins of the concept of non-violation complaints.

\section{The objective of the article}

The objective of the article is to summarize and analyze the available information on the historical tendencies that led to the establishment of the current WTO system with its combination of such clauses as the clause on the most-favored-nation treatment and the nonviolation clause.

\section{The most recent research and publications on the topic}

Some of the most recent works in the area relevant for the article include the works by Robert W. Staiger, Alan O. Sykes and Douglas A. Irwin. The article provides systemic analysis of the available publications to provide a consistent summary of the context for the current regionalist and globalist tendencies in international economic law.

\section{The main text of the article}

The non-violation clause, as included in Article XXIII of GATT 1947, is in subsection (b):

"Article XXIII Nullification or Impairment

1. If any contracting party should consider that any benefit accruing to it directly or indirectly under this Agreement is being nullified or impaired or that the attainment of any objective of the Agreement is being impeded as the result of (a) the failure of another contracting party to carry out its obligations under this Agreement, or (b) the application by another contracting party of any measure, whether or not it conflicts with the provisions of this Agreement, or (c) the existence of any other situation, the contracting party may, with a view to the satisfactory adjustment of the matter, make written representations or proposals to the other contracting party or parties which it considers to be concerned. Any contracting party thus approached shall give sympathetic consideration to the representations or proposals made to it".

It is notable that in GATT 1947 neither the term "nullification of benefits" nor the term "impairment of benefits" were defined. Also, the agreement did not determine how certain 
benefits accruing directly or indirectly are to be defined. Instead, it was left to GATT (and later WTO) dispute settlement panels to interpret these terms in the context of specific cases.

The very need to introduce non-violation clauses in international trade treaties is connected with the global process of gradual introduction of unconditional most favored treatment clauses (in contrast to earlier treaty practice, where most-favored-nation treatment was provided on a conditional basis).

One of the earliest attempts to establish the principle of unconditional most-favorednation treatment as a global uniform approach was made at the London World Economic Conference, the most ambitious global attempt to do so before the successful conclusion of the General Agreement on Tariffs and Trade in 1947.

In 1931 U.S. President Herbert Hoover called for an international conference to discuss policies with regard to establishment of tariffs and tariff policies. His call resulted in a series of interactions and negotiations between the interested parties and led to the expansion of the agenda topics for potential discussion to include reparations and war debts.

As a result of these and other political efforts, in 1932 the Lausanne Conference Protocol called for an international economic conference. The London World Economic Conference, which gathered representatives of 66 states from June 12 to July 27, 1933, put issues of liberalization of international trade at the center of the conference agenda. However, the London World Economic Conference failed to reach many of its objectives, in part due to disagreement by the parties on a number of interconnected issues of finance and trade.

As a partial response to this failure to achieve international consensus on the principles of trade liberalization, the United States at the national level adopted in 1934 the Reciprocal Trade Agreements Act. By 1945, more than 25 RTAA treaties had been concluded, reducing U.S. overall import duty rates by around 45 percent.

The need to reform the U.S. tariff policies based on 1930 Smooth-Haley Act, which instead of reducing only aggravated the effects of the Great Depression, was obvious. It was also clear that a more robust and flexible system of negotiation procedures had to be introduced to order to attain the goals of such reform.

The unilateral reduction of tariffs, which was quite easy in terms of procedure, was very difficult to achieve politically, as it was not realistic to aim to garner support from U.S. Congressmen for such unilateral action in the light of the ongoing economic problems in the United States.

Another option would be to engage in bilateral trade negotiations and coordinated reciprocal reductions of tariffs, which would achieve the double objective of providing the U.S. exporters with much needed opportunities to export their products and also allowing for increased healthy competition between imported and domestic products.

With regard to formulating the most-favored-nation (MFN) treatment clause U.S. President Harding explicitly adopted the unconditional MFN principle (which implicitly appeared in Section 317 of the Fordney - McCumber tariff of September 1922) in negotiating trade agreements, which was in contrast to the most of the earlier U.S. trade policies.

An example of conditional provision of the most-favored-nation treatment was the clause envisaged in the 1911 Treaty of Commerce and Navigation between the United States 
of America and Japan, whereby future preferences would be extended to the other party only with the expectation of an adequate compensation.

The unconditional provision of the most-favored-nation treatment was summarized in a statement by U.S. Senator Smoot:

"We would use the commercial policy of the United States upon the twin ideas of granting equal treatment to all nations in the market of the United States and of exacting equal treatment for the commerce of the United States in foreign markets. We do not believe that the United States should pursue a general policy of special bargains and special reciprocity treaties.... We stand for a simple, straightforward, friendly policy of equal treatment for all, without discriminations against any country except as that country has first discriminated against us" [2].

William Smith Culbertson, U.S. diplomat, as well as a member and later the President of the U.S. Tariff Commission, while arguing against conditional application of most-favorednation treatment, indicated that such application "affords no security against discrimination in foreign countries, and in this period of reconstruction, when many countries are revising their treaties and reconsidering their grants of most-favored-nation treatment, the conditional mostfavored-nation principle is liable to be applied against us" [5, 364].

The conclusion made by Culbertson indicated that "now that Congress has taken a definite stand for the policy of equality of treatment, it would seem to follow logically that in the revision of our commercial treaties we should adopt the unconditional form of the mostfavored-nation clause" $[5,365]$.

The new U.S. approach was implemented, inter alia, in the Treaty of Friendship, Commerce and Consular Relations between Germany and the United States of America, signed in Washington, D.C. on December 8, 1923.

Article VII of the Treaty provided:

"Between the territories of the High Contracting Parties there shall be freedom of commerce and navigation. The nationals of each of the High Contracting Parties equally with those of the most favored nation, shall have liberty freely to come with their vessels and cargoes to all places, ports and waters of every kind within the territorial limits of the other which are or may be open to foreign commerce and navigation. Nothing in this treaty shall be construed to restrict the right of either High Contracting Party to impose, on such terms as it may see fit, prohibitions or restrictions of a sanitary character designed to protect human, animal or plant life, or regulations for the enforcement of police or revenue laws. Each of the High Contracting Parties binds itself unconditionally to impose no higher or other duties or conditions and no prohibition on the importation of any article, the growth, produce or manufacture, of the territories of the other than are or shall be imposed on the importation of any like article, the growth, produce or manufacture of any other foreign country.

Each of the High Contracting Parties also binds itself unconditionally to impose no higher or other charges or other restrictions or prohibitions on goods exported to the territories of the other High Contracting Party than are imposed on goods exported to any other foreign country.

Any advantage of whatsoever kind which either High Contracting Party may extend to any article, the growth, produce, or manufacture of any other foreign country shall simultaneously 
and unconditionally, without request and without compensation, be extended to the like article the growth, produce or manufacture of the other High Contracting Party".

It should be noted that the global history of unconditional most-favored-nation treaty clauses dates back to the Cobden-Chevalier Treaty (UK-France Treaty of 1860). However, the events in the U.S. of 1920 s and 1930s signaled a fundamental shift in foreign economic policies of one of the leading major economic powers of the world, which was a very significant development with global consequences. In the light of the failure by the London World Economic Conference of 1933 to achieve many of its goals in the trade sphere, the steps by the United States to adopt and implement the Reciprocal Trade Agreements Act (RTAA) are especially notable.

The resulting treaty practice as embodied in dozens of U.S. trade agreements not only implemented this approach but also dealt with another potential problem - multiple opportunities for parties to such agreements to introduce various trade regulations which would negatively affect the potential of the relevant producers to export.

For example, the most-favored-nation clause, contained in Article X of the Reciprocal Trade Agreement between the U.S. and Venezuela, singed on November 6, 1939, is to some extent similar to the clause included in Article I of the General Agreement on Tariffs and Trade, namely with regard to its reference to any advantage, favor, privilege or immunity, origin of goods, as well as the immediacy and unconditionality of the most-favored-nation treatment.

At the same time, Article XVII of the same agreement contains the following clause:

"In the event that the Government of the United States of America or the Government of the United States of Venezuela adopts any measure, which, even though it does not conflict with the terms of this agreement, is considered by the Government of the other country to have the effect of nullifying or impairing any object of the Agreement, the Government which has adopted any such measures shall consider such representations and proposals as the other Government may make with a view to effecting a mutually satisfactory adjustment of the matter".

This is an earlier form of what later became a nullification or impairment (non-violation complaint) clause in GATT and other WTO agreements, such as Article 26 of the WTO Understanding on the Rules and Procedures Governing the Settlement of Disputes (DSU), Article XXIII (section 3) of the General Agreement on Trade in Services (GATS) and Article 64 of the Agreement on Trade-Related Aspects of Intellectual Property Rights (TRIPS).

Article 26 of the DSU provides:

"Where the provisions of paragraph 1(b) of Article XXIII of GATT 1994 are applicable to a covered agreement, a panel or the Appellate Body may only make rulings and recommendations where a party to the dispute considers that any benefit accruing to it directly or indirectly under the relevant covered agreement is being nullified or impaired or the attainment of any objective of that Agreement is being impeded as a result of the application by a Member of any measure, whether or not it conflicts with the provisions of that Agreement. Where and to the extent that such party considers and a panel or the Appellate Body determines that a case concerns a measure that does not conflict with the provisions of a covered agreement to which the provisions of paragraph 1(b) of Article XXIII of GATT 1994 are applicable, the procedures in this Understanding shall apply, subject to the following:

(a) the complaining party shall present a detailed justification in support of any complaint relating to a measure which does not conflict with the relevant covered agreement; 
(b) where a measure has been found to nullify or impair benefits under, or impede the attainment of objectives, of the relevant covered agreement without violation thereof, there is no obligation to withdraw the measure. However, in such cases, the panel or the Appellate Body shall recommend that the Member concerned make a mutually satisfactory adjustment;

(c) notwithstanding the provisions of Article 21, the arbitration provided for in paragraph 3 of Article 21, upon request of either party, may include a determination of the level of benefits which have been nullified or impaired, and may also suggest ways and means of reaching a mutually satisfactory adjustment; such suggestions shall not be binding upon the parties to the dispute;

(d) notwithstanding the provisions of paragraph 1 of Article 22, compensation may be part of a mutually satisfactory adjustment as final settlement of the dispute".

Article XXIII (section 3) of GATS provides:

"If any Member considers that any benefit it could reasonably have expected to accrue to it under a specific commitment of another Member under Part III of this Agreement is being nullified or impaired as a result of the application of any measure which does not conflict with the provisions of this Agreement, it may have recourse to the DSU. If the measure is determined by the DSB to have nullified or impaired such a benefit, the Member affected shall be entitled to a mutually satisfactory adjustment on the basis of paragraph 2 of Article XXI, which may include the modification or withdrawal of the measure. In the event an agreement cannot be reached between the Members concerned, Article 22 of the DSU shall apply".

Article 64 of the TRIPS Agreement provides:

"1. The provisions of Articles XXII and XXIII of GATT 1994 as elaborated and applied by the Dispute Settlement Understanding shall apply to consultations and the settlement of disputes under this Agreement except as otherwise specifically provided herein.

2. Subparagraphs 1(b) and 1(c) of Article XXIII of GATT 1994 shall not apply to the settlement of disputes under this Agreement for a period of five years from the date of entry into force of the WTO Agreement.

3. During the time period referred to in paragraph 2, the Council for TRIPS shall examine the scope and modalities for complaints of the type provided for under subparagraphs 1(b) and 1(c) of Article XXIII of GATT 1994 made pursuant to this Agreement, and submit its recommendations to the Ministerial Conference for approval. Any decision of the Ministerial Conference to approve such recommendations or to extend the period in paragraph 2 shall be made only by consensus, and approved recommendations shall be effective for all Members without further formal acceptance process".

It should be noted that the original five year moratorium on non-violation complaints with regard to intellectual property has been extended by WTO members.

The 2001 Doha Decision on Implementation-Related Issues and Concerns (in Paragraph 11.1) instructs the TRIPS Council to make a recommendation to the Cancun Ministerial Conference. Until then, members agreed not to file non-violation complaints under TRIPS.

However, no consensus has been reached so far. The moratorium has been extended several times, the latest being the extension from the 2017 Buenos Aires Ministerial Conference to the next meeting. At the time of writing of this article this moratorium was still in place. 
It should be kept in mind that non-violation clauses are not the exclusive feature of the WTO system. One of the relatively recent examples of a non-violation complaint clause in a trade treaty outside of the WTO agreements is Australia-United States Free Trade Agreement (AUSFTA), which came into effect on January 1, 2005 and which provides in Article 21.2 (c):

"Except as otherwise provided in this Agreement or as the Parties otherwise agree, the dispute settlement provisions of this Section shall apply with respect to the avoidance or settlement of all disputes between the Parties regarding the interpretation or application of this Agreement or wherever a Party considers that:

(a) a measure of the other party is inconsistent with its obligations under this Agreement (b) the other Party has otherwise failed to carry out its obligations under this Agreement; or (c) a benefit the Party could reasonably have expected to accrue to it under Chapters Two (National Treatment and Market Access for Goods [including Annex 2C on pharmaceuticals]), Three (Agriculture), Five (Rules of Origin), Ten (Cross-Border Trade in Services), Fifteen (Government Procurement) or Seventeen (Intellectual Property Rights) is being nullified or impaired as a result of a measure that is not inconsistent with this Agreement".

\section{Conclusion}

Considering the above information, it is possible to conclude that even though the original cause for non-violation complaints has been a relatively limited scope of the General Agreement on Tariffs and Trade, the significant expansion of the scope of application of this multilateral trade system as a result of the Uruguay Round of multilateral trade negotiations did not result in the removal of the original non-violation clause from the text of the GATT. Moreover, non-violation clauses were included in a number of other WTO agreements. This, in turn, leads to a question, whether indeed it would be possible at any time in the future to conclude an international trade agreement, which would cover each and every measure affecting international trade, available to national governments.

\section{Literature and sources:}

1. Robert W. Staiger, Alan O. Sykes. How Important Can the Non-Violation Clause Be for the GATT/WTO? American Economic Journal: Microeconomics 2017, 9(2), pp.149-187

2. Kenneth W. Dam. Cordell Hull, the Reciprocal Trade Agreements Act, and the WTO: An Essay on the Concept of Rights in International Trade. New York University Journal of Law and Business 709 (2005).

3. Clavin, Patricia. The World Economic Conference 1933: The Failure of British Internationalism. The Journal of European Economic History 20 (1991), pp. 489-527.

4. Sungjoon Cho. GATT Non-Violation Issues in the WTO Framework: Are They the Achilles' Heel of the Dispute Settlement Process? Harvard International Law Journal. Vol. 39, No. 2

5. Douglas A. Irwin. Clashing over Commerce: A History of US Trade Policy. University of Chicago Press, 2017

6. General Agreement on Tariffs and Trade (GATT). URL: https://www.wto.org/English/docs_e/legal_e/gatt47.pdf

7. WTO Understanding on the Rules and Procedures Governing the Settlement of Disputes (DSU). URL: https://www.wto.org/English/docs_e/legal_e/28-dsu.pdf

8. General Agreement on Trade in Services (GATS). URL: https://www.wto.org/English/docs_e/legal_e/26-gats.pdf

9. WTO Agreement on Trade-Related Aspects of Intellectual Property Rights (TRIPS). URL: https://www.wto.org/english/docs_e/legal_e/27-trips.pdf

10. WTO Doha Decision on Implementation-Related Issues and Concerns. URL: https://www.wto.org/english/res_e/booksp_e/ddec_e.pdf, pp. 27-43 
11. Reciprocal Trade Agreement between the U.S. and Venezuela, singed on November 6, 1939. URL: https://www.loc.gov/law/help/us-treaties/bevans/b-ve-ust000012-1141.pdf

12. John Vincent Nye. The Myth of Free-Trade Britain and Fortress France: Tariffs and Trade in the Nineteenth Century. - The Journal of Economic History. Vol. 51, No. 1 (March, 1991), pp. 23-46

13. Australia-United States Free Trade Agreement (AUSFTA). URL: https://dfat.gov.au/about-us/publications/trade-investment/australia-united-states-free-tradeagreement/Documents/Final_text_ausfta.pdf

14. Treaty of Friendship, Commerce and Consular Relations between Germany and the United States of America, signed in Washington, D.C. on December 8, 1923. URL: http://www.worldlii.org/int/other/LNTSer/1926/227.html

15. U.S. Reciprocal Trade Agreements Act of 1934. URL:

http://legisworks.org/congress/73/publaw-316.pdf 